\title{
The effect of industrial wastes and municipal sewage sludge compost on the quality of virginia fanpetals (SIDA HERMAPHRODITA RUSBY) biomass Part 1. Macroelements content and their upatke dynamics
}

\author{
Ewa Krzywy-Gawrońska \\ Western Pomeranian University of Technology, Szczecin, Department of Land Reclamation and Environmental Chemistry, \\ ul. Stowackiego 17, 71-434 Szczecin, Poland, e-mail: ewa.krzywy-gawronska@zut.edu.pl
}

\begin{abstract}
A single-factor field experiment was carried out at the Cultivar Evaluation Station in Szczecin-Dąbie in 2008-2010. In the experiment, the compost produced with municipal sewage sludge by the GWDA method was used and high-calcium brown coal ash at a dose corresponding. A test plant was Virginia fanpetals (Sida hermaphodrita Rusby). The obtained results show that Virginia fanpetals biomass contained on average the most nitrogen (3.72 $\left.\mathrm{g} \cdot \mathrm{kg}^{-1} \mathrm{~d} . \mathrm{m}.\right)$, calcium $\left(6.03 \mathrm{~g} \cdot \mathrm{kg}^{-1} \mathrm{~d} . \mathrm{m}\right.$.) and sulphur $\left(1.24 \mathrm{~g} \cdot \mathrm{kg}^{-1} \mathrm{~d} . \mathrm{m}.\right)$ in 2008 , while the most potassium (4.39 $\mathrm{g} \cdot \mathrm{kg}^{-1}$ d.m.) in 2010 . Significantly more phosphorus, magnesium and sulphur was contained by Virginia fanpetals biomass from the objects where municipal sewage sludge compost had been applied without and with addition of high-calcium brown coal ash when compared to calcium carbonate or high-calcium brown coal ash being introduced into soil at the beginning of study. Differences in average nitrogen, potassium and calcium contents in the test plant biomass from particular fertilisation objects were not significant. The macroelements uptake by Virginia fanpetals biomass depended on the yield size and the content of chemical elements under discussion in it.
\end{abstract}

Keywords: municipal sewage sludge,compost, calcium carbonate, high-calcium brown coal ash, Virginia fanpetals, macroelements content in soil and plant.

\section{INTRODUCTION}

During the technological process of brown coal combustion in heat generating plants and combined heat and power plants, the waste in the form of high-calcium brown coal ash is being obtained. Inappropriately controlled or managed brown coal ash may be a source of air, water and soil pollution. Substantial quantities of ash have been and are still being stored in landfill sites which occupy larger and larger areas and therefore should be excluded from environmental use. High-calcium brown coal ash are characterised by alkaline reaction ( $\mathrm{pH} 9-12.5)$, which is induced by high $\mathrm{CaO}$ and $\mathrm{MgO}$ contents. They are non-structural, fine grain material with predominance of the dust fraction $(0.1-0.02 \mathrm{~mm})$. Phosphorus and potassium contents in high-calcium brown coal ash are similar to their amounts being found in arable soils ${ }^{1-3}$.

Over the last several years, many new municipal sewage treatment plants have been modernised and constructed in Poland. The produced reclaimed wastewater are being drained to water streams or used or used in agriculture for spray irrigation of fields. The by-products being produced during sewage treatment, i.e. the wastes which include sewage sludge, pose a problem.

The sewage sludge coming from municipal sewage treatment plants are characterised by large manurial and soil-forming values. It was found, based on many chemical analyses, that composts being produced with sewage sludge contained considerably larger quantities of nutrients for plants, frequently exceeding their content in manure ${ }^{4-10}$.

To obtain a large quantity of Virginia fanpetals biomass, substantial quantities of nutrients are required which can be supplied among others in the form of composts produced with sewage sludge and other wastes, e.g. high-calcium brown coal ash.

The carried out study aimed at determining the direct effect and the after-effect of municipal sewage sludge compost applied without and with addition of highcalcium brown coal ash (waste) as a de-acidifying fertiliser on the content of nitrogen, potassium, phosphorus, magnesium, calcium and sulphur and the dynamics of their uptake by Virginia fanpetals (Sida hermaphodrita Rusby) biomass during three-year cultivation.

*Part of this study was conducted within the framework of a research and development project No. 0397/R/ $\mathrm{P} 01 / 2008 / 04$

\section{MATERIAL AND METHODS}

A single-factor field experiment was carried out at the Cultivar Evaluation Station in Szczecin-Dabie in 20082010 on $33 \mathrm{~m}^{2}$ experimental plots. Each experimental object was performed in four replications.

In respect of granulometric composition, the soil on which this experiment was set up is classified into the category of light soils, of soil quality class IVb and good rye complex. It had been formed from light loamy sand (lls). It was characterised by acidic reaction $\left(\mathrm{pH}_{\mathrm{KCl}} 5.30\right)$, which was an indication to carry out liming. The total content of macroelements for that type of soil was below average. The content of available forms of phosphorus was $24,8 \mathrm{mg} \cdot \mathrm{kg}^{-1}$ d.m. and it included the category of low abundance. Contrast, potassium and magnesium (120.0 and $47.0 \mathrm{mg} \cdot \mathrm{kg}^{-1}$ d.m.) to the category of average wealth. The content of organic carbon in the soil was low and amounted to $8.50 \mathrm{~g} \cdot \mathrm{kg}^{-1} \mathrm{~d} . \mathrm{m}$. The carbonto-nitrogen ratio $(\mathrm{C}: \mathrm{N})$ was $11.8: 1$ and was average for that type of soils. The content of microelements in the soil, including heavy metals, did not exceed the limits for the light soils being reported ${ }^{12}$. In the light of legislation in force, examinations with municipal sewage sludge composts and high-calcium brown coal ash could be 
carried out on such a soil ${ }^{13}$. In spring 2008, municipal sewage sludge compost produced by the GWDA method and calcium carbonate and high-calcium brown coal ash were introduced into soil. Dose levels for these fertiliser are given in Table 1. Thereafter, mineral fertilisation was applied as follows: $42.5 \mathrm{~kg} \mathrm{~N} \cdot \mathrm{ha}^{-1}$ was introduced into soil in the form of ammonium nitrate in the first year of experiment (2008) in May prior to sowing test plants, as well as $28 \mathrm{~kg} \mathrm{P} \cdot \mathrm{ha}^{-1}$ and $66.4 \mathrm{~kg} \mathrm{~K} \cdot \mathrm{ha}^{-1}$ in the form of multi-component fertiliser Suprofoska 20 (400 kg fertiliser per ha). The seedlings obtained from the rootstock division were planted on 15 May 2008; altogether, 20,000 seedlings were planted per 1 ha. Six weeks after planting Virginia fanpetals seedlings, $42.5 \mathrm{~kg} \mathrm{~N} \cdot \mathrm{ha}^{-1}$ was introduced into soil in the form of ammonium nitrate as the top dressing. In the second year of experiment (2009), a complex fertiliser Polimag $\mathrm{S}$ was introduced into soil in April at an $1000 \mathrm{~kg} \cdot \mathrm{ha}^{-1}$ dose. This corresponded to $100 \mathrm{~kg} \mathrm{~N} \cdot \mathrm{ha}^{-1}, 35 \mathrm{~kg} \mathrm{P} \cdot \mathrm{ha}^{-1}$, $125 \mathrm{~kg} \mathrm{~K} \cdot \mathrm{ha}^{-1}, 30 \mathrm{~kg} \mathrm{Mg} \cdot \mathrm{ha}^{-1}$ and $140 \mathrm{~kg} \mathrm{~S} \cdot \mathrm{ha}^{-1}$. In the third year of the experiment (2010), the same dose of complex fertiliser Polimag S as in 2009 was introduced into the soil in April. Eight weeks after the application of the complex fertiliser Polimag S in 2009 and 2010, $34 \mathrm{~kg} \mathrm{~N} \cdot \mathrm{ha}^{-1}$ was introduced into the soil in the form of ammonium nitrate. High-calcium brown coal ash was introduced into the soil in the objects with annual application in the beginning of April 2009 and 2010.

A test plant was Virginia fanpetals (Sida hermaphodrita Rusby) which was harvested after 226 days of vegetation in the first year of experiment, 188 days in the second year of the experiment and 194 days in the third year of the experiment.

The high-calcium brown coal ash used in this study came from the Pątnów-Adamów-Konin Power Plant Complex. It contained more potassium $\left(5.50 \mathrm{~g} \cdot \mathrm{kg}^{-1} \mathrm{~d} . \mathrm{m}\right.$.) than phosphorus $\left(2.52 \mathrm{~g} \cdot \mathrm{kg}^{-1} \mathrm{~d}\right.$.m.). This ash partly sup- plemented potassium deficiency in the compost. It was characterised by high value of $\mathrm{pH}_{\mathrm{KCl}}(11.0)$ and contained $986 \mathrm{~g} \cdot \mathrm{kg}^{-1}$ dry matter as well as $145 \mathrm{~g} \mathrm{Ca} \cdot \mathrm{kg}^{-1}$ d.m. and $12.5 \mathrm{~g} \mathrm{Mg} \cdot \mathrm{kg}^{-1}$ d.m. No nitrogen or organic carbon was found in the ash.

High calcium content in the ash used in this study (145 g Ca $\cdot \mathrm{kg}^{-1}$ d.m.) allowed it to be classified into the group of high-calcium ashes. The total content of cadmium (2.77 $\left.\mathrm{mg} \cdot \mathrm{kg}^{-1}\right)$, manganese $\left(265 \mathrm{mg} \cdot \mathrm{kg}^{-1}\right)$, nickel $\left(12.6 \mathrm{mg} \cdot \mathrm{kg}^{-1}\right)$, zinc (231.0 mg $\left.\mathrm{kg}^{-1}\right)$ and chromium $\left(20.6 \mathrm{mg} \cdot \mathrm{kg}^{-1}\right)$ in the examined high-calcium brown coal ash used in experiment was higher than in municipal sewage sludge compost. On the other hand, copper and lead contents (respectively 27.6 and 16.2 in $\mathrm{mg} \cdot \mathrm{kg}^{-1}$ ) were higher in the compost when compared to high-calcium brown coal ash. Taking into consideration the standards referring to the content of heavy metals in fertilisers for soil de-acidification ${ }^{13}$, high-calcium brown coal ash may by included among the factors affecting soil de-acidification without negative environmental impact.

The compost with municipal sewage sludge used in the experiment, produced by the GWDA method at the Municipal Sewage Treatment Plant in Stargard Szczeciński, corresponded, in respect to its chemical composition, to the standards allowing it to be classified into the group of organic fertilisers ${ }^{14}$. This compost had a $\mathrm{pH}_{\mathrm{H}_{2} \mathrm{O}}$ of 8.50 and therefore can be applied without fear on strongly acid and acid soils which constitute more than $50 \%$ in Poland ${ }^{15}$. The total content of nitrogen $\left(18 \mathrm{~g} \mathrm{~N} \cdot \mathrm{kg}^{-1} \mathrm{~d} . \mathrm{m}\right.$.) and phosphorus (10.2 $\mathrm{g} \mathrm{P} \cdot \mathrm{kg}^{-1} \mathrm{~d}$.m.) in this compost was clearly higher than that of potassium $\left(3.58 \mathrm{~g} \mathrm{~K} \cdot \mathrm{kg}^{-1} \mathrm{~d}\right.$.m.). Therefore, deficiencies of this chemical element should be supplemented in it with potassium mineral fertilisers.

The content of macroelements in Virginia fanpetals biomass in successive study years was determined in average samples from four replications of each fertilisation object. The nitrogen content was determined by Kjeldahl

Table 1. The content of nitrogen, phosphorus and potassium in Virginia fanpetals biomass in $\mathrm{g}^{\mathrm{kg}} \mathrm{g}^{-1}$

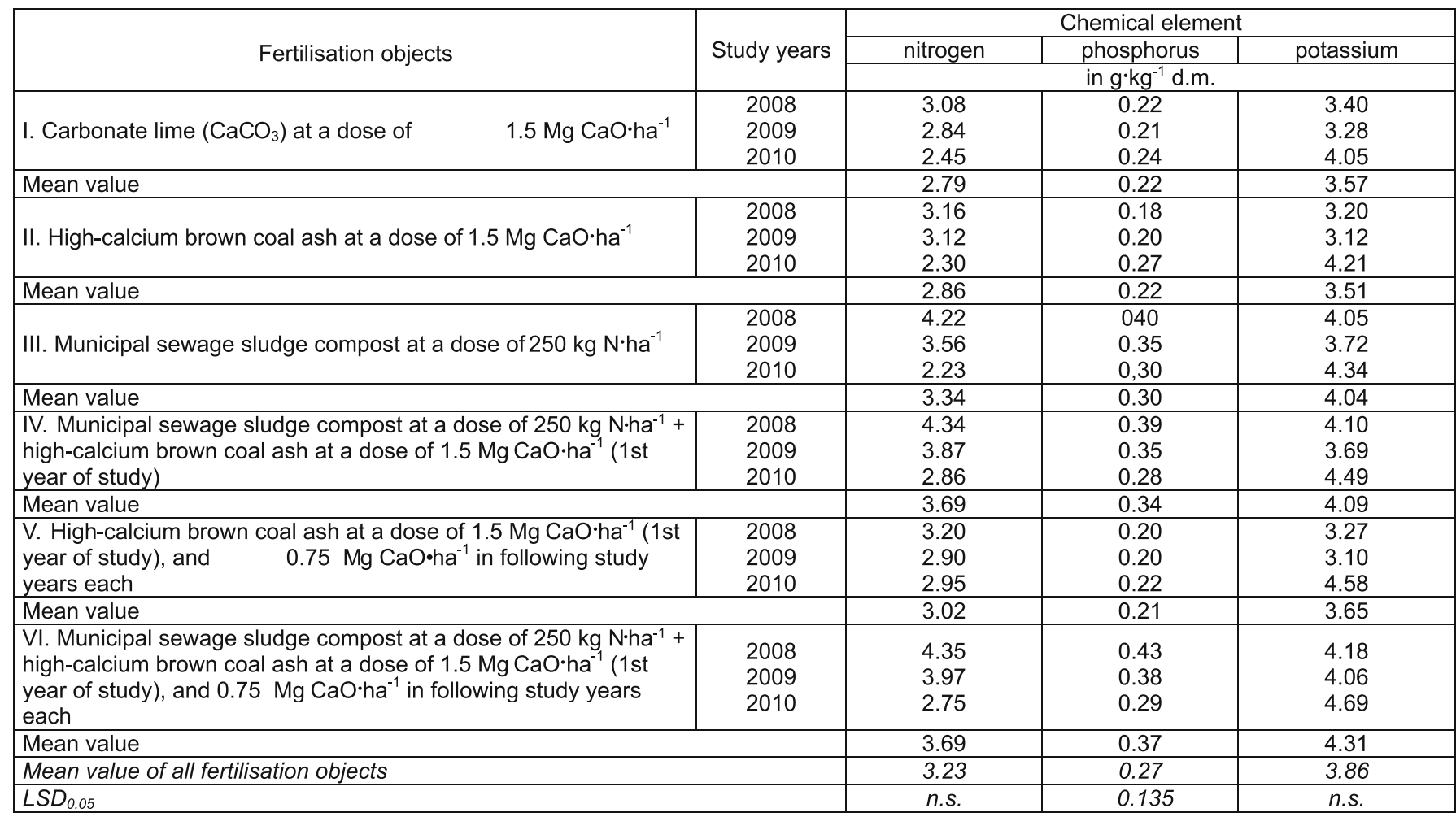


method (PN ISO 13878), the phosphorus content by the colorimetric method according to Barton and that of sulphur by means of the nefelometric method on a Perkin Elmer Lambda EZ 150 apparatus, while potassium, magnesium and calcium contents by the method of atomic absorption spectrometry on a Perkin Elmer AAS 300 spectrometer. The stock solution was obtained after previous wet mineralisation of plant material according to the Polish standards PN-ISO 11466 and PN-ISO 11047.

The content of macroelements was processed statistically by the analysis of variance method according to Statistica 8.0 PL computer software package. In the case of significant differences, the Tukey's test was used at significance level $\mathrm{p}=0.05$.

\section{RESULTS AND DISCUSSION}

The excessive content or deficiency of macroelements in plants may reduce their quality being considered from the point of view of industrial processing. This also points to the dynamics of nutrients passage from soils to plants ${ }^{16-17}$. Virginia fanpetals biomass contained on average the most nitrogen $\left(3.72 \mathrm{~g} \cdot \mathrm{kg}^{-1} \mathrm{~d} . \mathrm{m}\right.$.), calcium $\left(6.03 \mathrm{~g} \cdot \mathrm{kg}^{-1}\right.$ d.m.) and sulphur (1.24 g. $\mathrm{kg}^{-1}$ d.m.) in 2008 , while the most potassium (4.39 g. $\mathrm{kg}^{-1}$ d.m.) in 2010 (Tab. 1 and 2). Based on the data reported ${ }^{18-19}$, it can be stated that nitrogen, potassium and calcium contents in Virginia fanpetals biomass being obtained in the present study were average, whereas phosphorus and magnesium ones were half as high.

Average phosphorus and magnesium contents in the biomass of test plant in the particular study years slightly differed and amounted, respectively, to 0.27 to $0.30 \mathrm{~g} \mathrm{P} \cdot \mathrm{kg}^{-1} \mathrm{~d}$.m. and 0.69 to $0.78 \mathrm{~g} \mathrm{Mg} \cdot \mathrm{kg}^{-1} \mathrm{~d}$.m. Higher macroelements content was found in the biomass of test plant from the objects where municipal sewage sludge had been applied without and with addition of high-calcium brown coal ash (fertilisation objects III, IV and VI) when compared to those where organic fertilisation had not been used (fertilisation objects I, II and V). However, differences in the average content of nitrogen, potassium and calcium in Virginia fanpetals biomass between respective experimental objects were not significant (Tab. 1 and 2).

On average, more nitrogen was contained by Virginia fanpetals biomass from the objects where municipal sewage sludge compost had been applied without and with addition of high-calcium brown coal ash (respectively 3.34 and $3.69 \mathrm{~N} \mathrm{~g} \cdot \mathrm{kg}^{-1}$ ) when compared to calcium carbonate $\left(2.79 \mathrm{~g} \mathrm{~N} \cdot \mathrm{kg}^{-1}\right)$ or high-calcium brown coal ash $(2.86 \mathrm{~g}$ $\mathrm{N} \cdot \mathrm{kg}^{-1}$ ) (fertilisation objects I and II). Differences in the average content of nitrogen in test plants from the objects with municipal sewage sludge compost without and with addition of high-calcium brown coal ash were not significant. No significant differences were observed either in average nitrogen content in test plant biomass between the objects where only calcium carbonate or high-calcium brown coal ash had been introduced into soil at a dose of $1.5 \mathrm{Mg} \mathrm{CaO} \cdot \mathrm{ha}^{-1}$ (Tab. 1). Average increase in the nitrogen content in the test plant biomass was found, respectively by $25.8 \%$ and $22.7 \%$, between the objects where organic fertilisation had been applied without and with addition of high-calcium brown coal ash when compared to those with high-calcium brown coal ash or calcium carbonate.

Significantly more phosphorus $\left(0.37 \mathrm{~g} \mathrm{P} \cdot \mathrm{kg}^{-1} \mathrm{~d}\right.$.m. $)$ was contained by Virginia fanpetals biomass from the object with municipal sewage sludge compost and high-calcium brown coal ash being introduced into soil at a dose of $1.5 \mathrm{Mg} \mathrm{CaO} \cdot \mathrm{ha}^{-1}$ in the first year of study and $0.75 \mathrm{Mg}$ $\mathrm{CaO} \cdot \mathrm{ha}^{-1}$ in following study years when compared to those with calcium carbonate and high-calcium brown coal ash being applied at the beginning of experiment and annually (fertilisation objects I, II and V).

Increase in the phosphorus content between these objects amounted respectively to $68.2 \%$ and $76.2 \%$. Differences in average phosphorus content Virginia fanpetals biomass between the objects with municipal sewage sludge compost without and with addition of high-calcium brown coal ash were not significant (Tab. 1).

The most potassium was contained by the biomass of test plant from object VI, i.e. $4.31 \mathrm{~g} \mathrm{~K} \cdot \mathrm{kg}^{-1}$ d.m., when compared to other fertilisation objects (Tab. 1). Differences in average potassium content in the biomass of test plant harvested from respective fertilisation objects were not significant (Tab. 1). However, despite the lack of significant differences in the potassium content in test plant biomass, an increase was found between this object (fertilisation object VI) and other ones (fertilisation objects I, II, III, IV and V), respectively by $20.7 \%$, $22.8 \%, 6.68 \%, 5.37 \%$ and $18.1 \%$.

On average, significantly more magnesium was contained by test plant biomass from the object where municipal sewage sludge compost had been applied with annual introduction of high-calcium brown coal ash into soil $\left(0.86 \mathrm{~g} \mathrm{Mg} \cdot \mathrm{kg}^{-1}\right.$ d.m.) when compared to that where only calcium carbonate had been applied $(0.60 \mathrm{~g}$ $\mathrm{Mg} \cdot \mathrm{kg}^{-1} \mathrm{~d} . \mathrm{m}$.). Average increase of its content in Virginia fanpetals biomass between these objects amounted to $43.3 \%$ (Tab. 2).

On average, the least calcium was contained by test plant biomass from the object with calcium carbonate being introduced into soil at a dose of $1.5 \mathrm{Mg} \mathrm{CaO} \cdot \mathrm{ha}^{-1}$ (5.14 Ca g. $\mathrm{kg}^{-1}$ d.m.) when compared to other fertilisation objects (Tab. 2). Differences in average calcium content in the biomass of test plant harvested from particular fertilisation objects were not significant (Tab. 2). Despite the lack of significant differences in the calcium content in test plant biomass, an increase was found in its content between fertilisation object I and other ones (fertilisation objects II, III, IV, V and VI), respectively by $7.78 \%, 10.9 \%, 25.1 \%, 13.03 \%$ and $20.6 \%$.

Average sulphur content in Virginia fanpetals biomass amounted to $1.14 \mathrm{~g} \cdot \mathrm{kg}^{-1} \mathrm{~d} . \mathrm{m}$. It was five times higher when compared to that reported ${ }^{20-21}$ which amounted respectively to 0.25 and $0.33 \mathrm{~g} \mathrm{~S} \cdot \mathrm{kg}^{-1} \mathrm{~d} . \mathrm{m}$. When comparing the obtained study results, it can be stated that the content of nitrogen in Virginia fanpetals biomass was similar, that of phosphorus and potassium was slightly lower, that of calcium was half as low, while that of magnesium was one time higher when compared to the findings being reported ${ }^{21}$.

Average increase in the macroelements uptake by Virginia fanpetals biomass from the objects being fertilised with municipal sewage sludge compost without and with addition of high-calcium brown coal ash at the begin- 
Table 2. The content of calcium, magnesium and sulphur in Virginia fanpetals biomass in $\mathrm{g} \cdot \mathrm{kg}^{-1} \mathrm{~d} . \mathrm{m}$.

\begin{tabular}{|c|c|c|c|c|}
\hline \multirow{3}{*}{\begin{tabular}{|l|} 
Fertilisation objects \\
\end{tabular}} & \multirow[t]{3}{*}{ Study years } & \multicolumn{3}{|c|}{ Chemical element } \\
\hline & & calcium & magnesium & sulphur \\
\hline & & \multicolumn{3}{|c|}{ in $\mathrm{g} \mathrm{kg}^{-1} \mathrm{~d} . \mathrm{m}$. } \\
\hline I. Carbonate lime $\left(\mathrm{CaCO}_{3}\right)$ at a dose of $1.5 \mathrm{Mg} \mathrm{CaO} \cdot \mathrm{ha}^{-1}$ & $\begin{array}{l}2008 \\
2009 \\
2010\end{array}$ & $\begin{array}{l}5.52 \\
5.30 \\
4.60\end{array}$ & $\begin{array}{l}0.63 \\
0.58 \\
0.60\end{array}$ & $\begin{array}{l}0.90 \\
0.90 \\
0.95\end{array}$ \\
\hline Mean value & & 5.14 & 0.60 & 0.92 \\
\hline II. High-calcium brown coal ash at a dose of $1.5 \mathrm{Mg} \mathrm{CaO} \mathrm{ha}^{-1}$ & $\begin{array}{l}2008 \\
2009 \\
2010\end{array}$ & $\begin{array}{l}5.82 \\
5.50 \\
5.30\end{array}$ & $\begin{array}{l}0.67 \\
0.62 \\
0.73\end{array}$ & $\begin{array}{l}0.94 \\
0.82 \\
1.02\end{array}$ \\
\hline Mean value & & 5.54 & 0.67 & 0.93 \\
\hline III. Municipal sewage sludge compost at a dose of $250 \mathrm{~kg} \mathrm{~N} \cdot \mathrm{ha}^{-1}$ & $\begin{array}{l}2008 \\
2009 \\
2010\end{array}$ & $\begin{array}{l}6.31 \\
6.08 \\
4.70\end{array}$ & $\begin{array}{l}0.88 \\
0.84 \\
0.81\end{array}$ & $\begin{array}{l}1.50 \\
1.45 \\
0.86\end{array}$ \\
\hline Mean value & & 5.70 & 0.84 & 1.27 \\
\hline $\begin{array}{l}\text { IV. Municipal sewage sludge compost at a dose of } 250 \mathrm{~kg} \mathrm{~N}^{-1} \mathrm{Na}^{-1}+ \\
\text { high-calcium brown coal ash at a dose of } 1.5 \mathrm{Mg} \mathrm{CaO} \cdot \mathrm{ha}^{-1} \text { ( } 1 \mathrm{st} \text { year } \\
\text { of study) }\end{array}$ & $\begin{array}{l}2008 \\
2009 \\
2010\end{array}$ & $\begin{array}{l}6.19 \\
6.29 \\
6.81\end{array}$ & $\begin{array}{l}0.86 \\
0.72 \\
0.83\end{array}$ & $\begin{array}{l}1.58 \\
1.48 \\
0.92\end{array}$ \\
\hline Mean value & & 6.43 & 0.80 & 1.33 \\
\hline $\begin{array}{l}\text { V. High-calcium brown coal ash at a dose of } 1.5 \mathrm{Mg} \mathrm{CaO}^{-1} \mathrm{ha}^{-1} \text { (1st } \\
\text { year of study), and } \quad 0.75 \mathrm{Mg} \mathrm{CaO} \cdot \mathrm{ha}^{-1} \text { in following study } \\
\text { years each }\end{array}$ & $\begin{array}{l}2008 \\
2009 \\
2010\end{array}$ & $\begin{array}{l}5.82 \\
5.30 \\
6.32\end{array}$ & $\begin{array}{l}0.65 \\
0.54 \\
0.86\end{array}$ & $\begin{array}{l}0.95 \\
0.86 \\
1.01\end{array}$ \\
\hline Mean value & & 5.81 & 0.68 & 0.94 \\
\hline $\begin{array}{l}\text { Vl. Municipal sewage sludge compost at a dose of } 250 \mathrm{~kg} \mathrm{~N}^{-1} \mathrm{ha}^{-1}+ \\
\text { high-calcium brown coal ash at a dose of } 1.5 \mathrm{Mg} \mathrm{CaO} \cdot \mathrm{ha}^{-1}(1 \mathrm{st} \\
\text { year of study), and } 0.75 \mathrm{Mg} \mathrm{CaO} \cdot \mathrm{ha}^{-1} \text { in following study years each }\end{array}$ & $\begin{array}{l}2008 \\
2009 \\
2010\end{array}$ & $\begin{array}{l}6.52 \\
6.20 \\
5.87\end{array}$ & $\begin{array}{l}0.88 \\
0.84 \\
0.85\end{array}$ & $\begin{array}{l}1.60 \\
1.64 \\
1.07\end{array}$ \\
\hline Mean value & & 6.20 & 0.86 & 1.44 \\
\hline Mean value of all fertilisation objects & & 5.80 & 0.74 & 1.14 \\
\hline$L S D_{0.05}$ & & n.s. & 0.195 & 0.365 \\
\hline
\end{tabular}

ning of study and annually (fertilisation objects III, IV and VI) amounted to $41.1 \%$ for nitrogen, $31.2 \%$ for potassium, $39.6 \%$ for calcium, $59.3 \%$ for magnesium and $55.5 \%$ for sulphur when compared with that being fertilised with calcium carbonate only (fertilisation object I). The least phosphorus uptake by Virginia fanpetals biomass was found in the object with high-calcium brown coal ash being introduced into soil at a dose of $1.5 \mathrm{Mg}$ $\mathrm{CaO} \cdot \mathrm{ha}^{-1}$ in the first year of study and $0.75 \mathrm{Mg} \mathrm{CaO} \cdot \mathrm{ha}^{-1}$ in following study years, i.e. $7.28 \mathrm{~g} \cdot \mathrm{kg}^{-1} \mathrm{~d}$.m. (Tab. 3).

Decidedly more nitrogen, phosphorus, potassium, calcium, magnesium and sulphur was contained by Virginia fanpetals biomass from the objects where municipal sewage sludge compost and high-calcium brown coal ash had been applied when compared to those where organic fertilisation had not been used. The obtained study results show that macroelements contained in the compost affected the increase of their content in test plant biomass.

The studies carried out ${ }^{22-27}$ confirm that sewage sludge and composts produced with it affect plant yield increase, their macroelements content and uptake as well as improve soil water and air properties, stabilise their reaction and increase their organic matter content.

The increase in the macroelements content in Virginia fanpetals biomass and at the same higher macroelements uptake in it in the objects with municipal sewage sludge and high-calcium brown coal as compared to that where only municipal sewage sludge compost had been applied may be substantiated by the effect of calcium and soil $\mathrm{pH}\left(\mathrm{pH}_{\mathrm{KCL}}\right)$ on the intensity of microbiological processes taking place in soil. This is confirmed by the study results being obtained ${ }^{28-32}$ which found that nutrients being so far non-assimilable by plants turn into available forms as a result of these processes, and thus a plant is able to absorb them.

The total uptake of macroelements by Virginia fanpetals biomass was by far the least in the objects with calcium carbonate and high-calcium brown coal ash (fertilisation objects I and II). However, these statistical differences 
Table 3. The total macroelements uptake by Virginia fanpetals biomass in 2008-2010. The data are given in $\mathrm{kg} \cdot \mathrm{ha}^{-1} \mathrm{~d} \cdot \mathrm{m}$.

\begin{tabular}{|c|c|c|c|c|c|c|}
\hline \multirow{3}{*}{ Fertilisation objects } & \multicolumn{6}{|c|}{ Chemical element } \\
\hline & $\mathrm{N}$ & $\mathrm{P}$ & $\mathrm{K}$ & $\mathrm{Mg}$ & $\mathrm{Ca}$ & $S$ \\
\hline & \multicolumn{6}{|c|}{ in kg•ha ${ }^{-1}$ d.m. } \\
\hline 1 & 88.1 & 7.46 & 121.4 & 19.6 & 164.3 & 30.6 \\
\hline II & 89.9 & 7.68 & 120.1 & 22.3 & 179.0 & 30.5 \\
\hline III & 110.3 & 12.2 & 150.4 & 30.8 & 201.9 & 43.4 \\
\hline IV & 130.1 & 12.2 & 156.9 & 29.9 & 249.5 & 46.3 \\
\hline $\mathrm{V}$ & 102.1 & 7.28 & 133.1 & 24.4 & 202.4 & 32.6 \\
\hline $\mathrm{VI}$ & 137.5 & 13.2 & 170.7 & 33.0 & 236.3 & 53.0 \\
\hline $\mathrm{LSD}_{0.05}$ & 16.7 & n.s. & 13.8 & n.s. & n.s. & n.s. \\
\hline
\end{tabular}

* Description of fertilisation objects is given in Table 1.

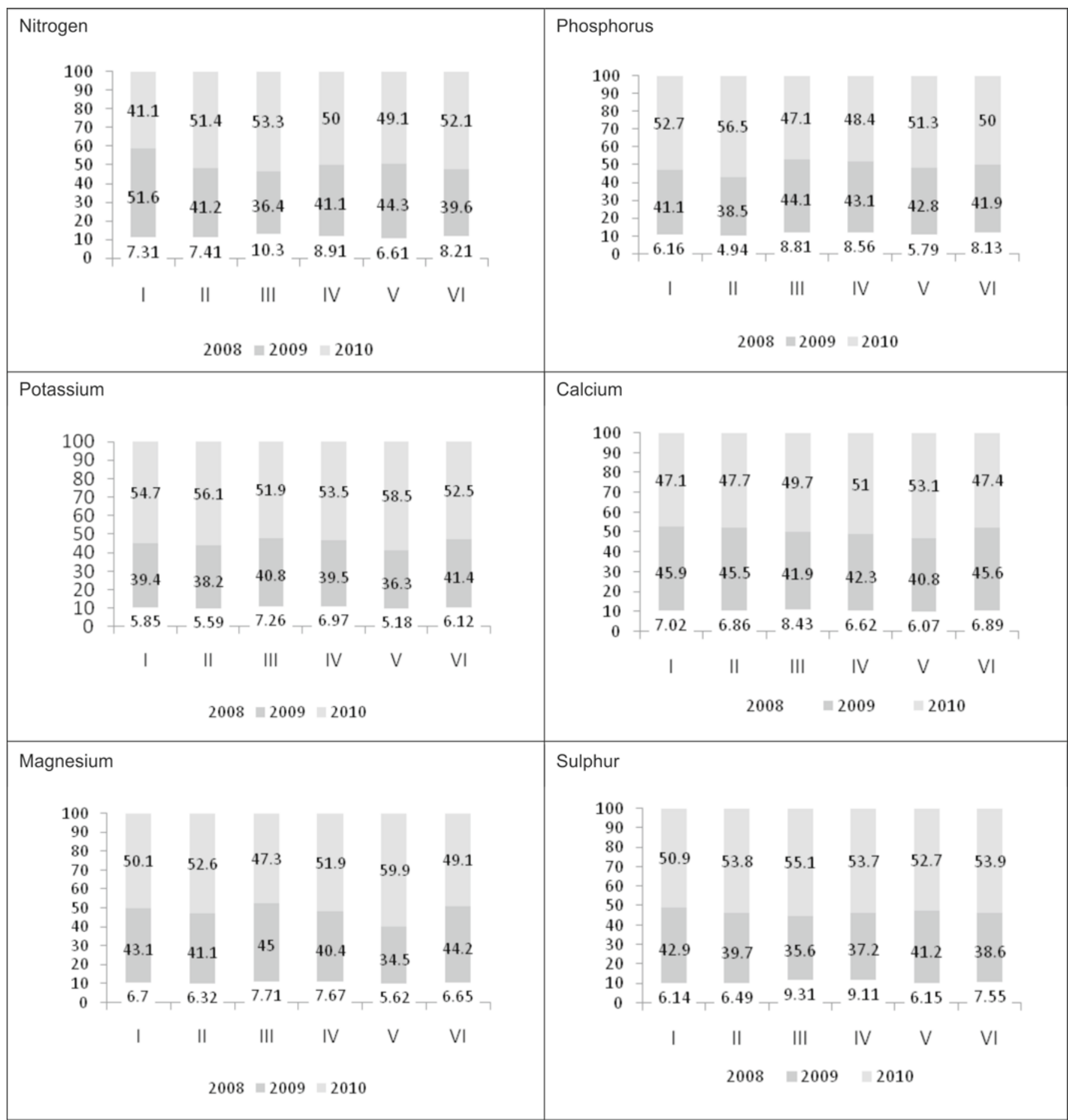

Figure 1. The dynamics of macroelements uptake by Virginia fanpetals biomass in successive years of cultivation in relative values (total uptake $=100 \%$ ). Description of fertilisation objects (I to VI) is given in Table 1 
were proved only in case of nitrogen and potassium. The highest uptake of macroelements during three study years was found in fertilisation objects III, IV and VI (Tab. 3).

The applied calcium carbonate and high-calcium brown coal ash being introduced into the soil at the beginning of the study (fertilisation objects I and II) induced a significant decrease in the total macroelements uptake when compared to other fertilisation objects. When analysing the dynamics of macroelements uptake, it was found to be decidedly lower in the first year of study and ranged from $4.94 \%$ to $10.3 \%$. It increased in the next study years, reaching the highest value of $58.5 \%$ in the last year of study. The macroelements uptake by Virginia fanpetals biomass depended on the yield size and the content of the chemical elements under discussion (Fig.1.).

It results from the carried out examinations that there is a correlation between the municipal sewage sludge compost and high-calcium brown coal ash leading to an increase in the macroelements content and their uptake by Virginia fanpetals biomass.

\section{CONCLUSIONS}

1. Virginia fanpetals biomass contained on average the most nitrogen $\left(3.72 \mathrm{~g} \cdot \mathrm{kg}^{-1} \mathrm{~d} . \mathrm{m}.\right)$, calcium $\left(6.03 \mathrm{~g} \cdot \mathrm{kg}^{-1}\right.$ d.m.) and sulphur (1.24 g. $\mathrm{kg}^{-1} \mathrm{~d} . \mathrm{m}$.) in 2008, while the most potassium (4.39 $\mathrm{g} \cdot \mathrm{kg}^{-1}$ d.m.) in 2010 .

2. Municipal sewage sludge compost with the addition of high-calcium brown coal ash being applied in the first year of study and annually contributed to the increase of average content of nitrogen, phosphorus, magnesium and sulphur in Virginia fanpetals biomass, respectively by $32.2 \%, 68.2 \%, 43.3 \%$ and $56.5 \%$, when compared to the fertilisation object with calcium carbonate.

3. Significantly more phosphorus, magnesium and sulphur was contained by Virginia fanpetals biomass from the objects where municipal sewage sludge compost had been applied without and with addition of high-calcium brown coal ash when compared to calcium carbonate or high-calcium brown coal ash being introduced into soil at a dose of $1.5 \mathrm{t} \mathrm{CaO} \cdot \mathrm{ha}^{-1}$.

4. Differences in average nitrogen, potassium and calcium contents in the test plant biomass from particular fertilisation objects were not significant.

5. The macroelements content in the biomass of Virginia fanpetals under cultivation (mean value of three harvests during three years of its cultivation) can be arranged in the following descending order: $\mathrm{Ca}>\mathrm{K}>$ $\mathrm{N}>\mathrm{S}>\mathrm{Mg}>\mathrm{P}$.

6. Total macroelements uptake by Virginia fanpetals was by far the least in the objects with calcium carbonate and high-calcium brown coal ash. The highest uptake of macroelements during three study years was found in the objects with municipal sewage sludge compost without and with addition of high-calcium brown coal ash (fertilisation objects III, IV and VI).

\section{LITERATURE CITED}

1. Maciak, F. \& Hrynkiewicz S. (1990). Agricultural land reclamation of derelict areas with heat and power plant ash application. Study commissioned by the Żerań Heat and Power Plant, Warszawa [in Polish].

2. Meller, E., Niedźwiedzki, E., \& Meller, E. (2001). The properties of ash from combustion at the Dolna Odra Power Plant stored on a plant landfill site. Fol. Univ. Stetinensis, Agricultura 78: 167-178 [in Polish].

3. Stankowski, S. \& Krzywy, E. (2004). The content of primary plant nutrients and heavy metals in top layers and substrates of the land reclamation model consisting of hard coal ash and municipal sewage sludge. Part 1 . The content of primary plant nutrients. Zesz. Probl. Post. Nauk Rol. 499: 315-323 [in Polish].

4. Maćkowiak, C. (2001). The manurial value of sewage sludge. Inż. Ekol. 3, 135-145 [in Polish].

5. Czekała, J. (2002). The humus-forming value and the manurial effect of sewage sludge. Folia Univ. Agric. Stetin. Ser. Agriculturae 211(84), 75-80 [in Polish].

6. Czekała, J. (2008). Chemical properties of the compost produced from sewage sludge and different bio-wastes]. Journal of Research and Applications in Agricultural Engineering. Vol. 53 (3), 35-41 [in Polish].

7. Iżewska, A. (2009). The usefulness of composts from municipal sewagesludge to fertilize the grass Miscanthus sugar miskantusa sacchariflorus (Maxim. Hack.). Monografia Wyd. ZUT w Szczecinie ss: 108 [in Polish].

8. Hargreaves, J.C., Adl, M.S.\& Warman P.R. (2008): A review of the use of composted municipal solid waste in agriculture. Agric. Ecosys. Environ. 123: 1-14. DOI. 10.1016/j. agee.2007.07.004

9. Harrison, E.Z., Oakes, S.R., Hysell, M. \& Hay, A. (2006). Organic chemical in sewage sludge. Science of the Rotal Enviroment 367:481-497. DOI: 10.1016/j.scitotenv.2006.04.002.

10. Roca-Perez, L., Martinez, C., Marcilla, P. \& Boluda R. (2009). Composting rice straw with sewage sludge and compost effects on the soil-plant system. Chemosphere 75, 6:58-65.. DOI:10.1016/j.chemosphere. 2008.12.058.

11. Eriksson, E., Christensen, N., Schmidt, J.F. \& Ledin, A. (2008). Protential priority pollutants in sewage sludge. Elserier 226, 371-388. DOI: 10.1016/j.desol.2007.03.019.

12. Filipek, T. (2006). Chemia rolna. Podstawy teoretyczne i analityczne. Wydaw. AR Lublin, 282 [in Polish].

13. Regulation of the Minister of Environment on municipal sewage sludge. Official Journal of Laws No. 137, item 924 of 2010 [in Polish].

14. Regulation of the Minister of Agriculture and Rural Development of 18 June 2008 on the execution of some provisions of the Act on fertilisers and fertilisation. Official Journal of Laws No. 119, item 765 of 2 July 2008 [in Polish].

15. Statistical Yearbook of the Republic of Poland 2009. GUS Warszawa [in Polish].

16. Czuba, R. \& Mazur, T. (1988). The effect of fertilisation on the yield quality. $P W N$, Warszawa [in Polish].

17. Stanisławska-Glubiak, E. \& Korzeniowska, J., (2007). Evaluation of plant nutrition state. Oddział Krakowskiego Polskiego Towarzystwa Inżynierii Ekologicznej, Stacja Chemiczno- Rolnicza, 5-21 [in Polish].

18. Kuś, J. \& Matyka, M. (2010). Selected elements of the agrotechnique of plants cultivated for energy purposes. Modern technologies of biomass harvesting and its energy use. Instytut Energetyki: 101-120 [in Polish].

19. Łabętowicz, J. \& Stępień, W. (2010). Fertilisation of energy plants (willow, Amur silver grass [silver banner grass], Virginia fanpetals). Modern technologies of biomass harvesting and its energy use. Instytut Energetyki: 89-100 [in Polish].

20. Tworkowski, J., Stolarski, M. \& Wróblewska, H. (2010). The chemical composition and energy value of shrub willow, Virginia fanpetals and giant Chinese silver grass. Zesz. Probl. Post. Nauk Rol. 547: 401-408 [in Polish].

21. Winnicka, G., Matuszek, K., \& Wilk, B. (2010). Solid biofuel standardisation, certification and processing technologies. Modern technologies of biomass harvesting and its energy use. Instytut Energetyki: 145-158 [in Polish].

22. Baran, S. (2004). Sewage sludge in agro-ecological economy. Zesz. Prob. Post. Nauk Rol. 499, 15-20 [in Polish]. 
23. Baran, S. (2005). Organic waste resources and management in Poland. Selected aspects of organic waste disposal and energy willow biomass production. URzeszow, Rzeszów, 17-40 [in Polish].

24. Kalembasa, S. \& Synamowicz, B. (1999). The effect of mineral fertilisation, sewage sludge mixtures with bark and sawdust on the crop yield and chemical composition of Lolium multiflorum Lam, Folia Univ. Agric. Stetin. Ser Agricultura 200 (77): 129-134 [in Polish].

25. Krzywy, E., Iżewska, A. \& Jeżowski, S. (2003). Evaluation of the possibility of using municipal sewage sludge for fertilisation of Amur silver grass [silver banner grass Miscanthus sacchariflorus (Maxim.) Hack. Zesz. Probl. Post. Nauk Rol. 494: 215-223 [in Polish].

26. Kalembasa, D. \& Malinowska, E. (2007). The effect of sewage sludge doses on the yield and chemical composition of Miscanthus sacchariflorus grass. Fragm. Agron. 24 (93): 113-117 [in Polish].

27. Wołoszyk, C. (2003). Agrochemical evaluation of the fertilisation with municipal sewage sludge composts and industrial wastes. Habilitation treatise No. 217. Akademia Rolnicza w Szczecinie, 120 [in Polish].

28. Maciejewska, A. (1998). Brown coal as a source of organic matter and its effect on soil properties, Politech. Warszawska: 52-67 [in Polish].

29. Mocek, A., Drzymała, S. \& Maszner, P. (1997). Soil genesis, analysis and classification. Akademia Rolnicza, Poznań: 243 [in Polish].

30. Wysokiński, A. \& Kalembasa, S. (2006). Selected physicochemical parameters of fresh and composted sewage sludge and their mixtures with $\mathrm{CaO}$ or brown coal ash. Acta Sci. Pol. Formatio Circumietus 5 (1): 51-61 [in Polish].

31. Wysokiński, A. \& Kalembasa, S. (2006). The effect of sewage sludge composts with calcium oxide and brown coal ash and calcium and magnesium contents in plants. Zesz. Prob. Post. Nauk Rol. 512 Part 2: 659-667 [in Polish].

32. Stankowski, S., Gibczyńska, M., Bielińska, E.J., Szczygielski, T. \& Kanafek, J. (2006). Ashes from power engineering - evaluation of their usefulness for fertilisation purposes, UPS, Puławy: 7-35 [in Polish]. 